\title{
Spillover Effect of Global Financial Cycle To Asset Markets in Asean-5 Countries: A Structural VAR Approach
}

\author{
Sri Andaiyani ${ }^{*}$ and Telisa Aulia Falianty ${ }^{2}$ \\ ${ }^{1,2}$ University of Indonesia, Depok, Indonesia
}

\begin{abstract}
An upsurge and volatility of capital flows to Emerging Asian Economies indicated that there is the potential effect of global financial cycle to emerging market. It provides an overview of investor risk aversion in short term investment after financial crisis 2008. Global financial cycle could have a significant impact to asset prices, including equity prices and property prices. Rey (2015) has triggered an interesting discussion about global financial cycle. She found that there was a global financial cycle in capital flows, asset prices and credit growth. This cycle was co-moves with the VIX, a measure of uncertainty and risk aversion of the markets. Therefore, this study attempts to analyze empirically global financial cycle shocks, measured by the VIX, on equity prices and property prices in ASEAN5, namely Indonesia, Malaysia, Singapore, Thailand and Philippines. We estimate quarterly frequency data from Q1 1990 to Q2 2016 with Structural Vector Autoregressive (SVAR) approach. The result of this study showed that global financial cycle has a negative significant impact on the ASEAN-5 asset markets, in spite of the response of shock differs by country and size. This result is consistent with ASEAN-5 as small open economies that remain vulnerable to the global factor. This study contributes to the literature in several ways. First, we identify not only cyclical expansions or contraction in asset markets but also the impact of global financial cycle to asset markets in ASEAN-5 countries. Second, we investigate whether there are heterogeneous responses of ASEAN-5 countries to global financial cycle shocks. Third, we also identify the pattern of cycle in ASEAN-5 countries.
\end{abstract}

JEL Classification: F30, F37, F42

Keywords: ASEAN, Asset Markets, Global Financial Cycle, SVAR

\section{INTRODUCTION}

Recent empirical study on global financial cycles devotes more attention to academicians and policy makers. An upsurge and volatility of capital flows to Emerging Asian Economies indicated that there is the potential effect of global financial cycle to emerging market. However, in the last three years there have been concerns about a decrease in capital flows to developing countries or massive capital reversals with the issue of "tapering off". Global financial crisis 2007/2008 can be one of the empirical evidence that domestic financial markets was

* Corresponding author. Email address: telisa97fe@gmail.com 
influenced by global financial conditions. Bruno and Shin (2015) stated that the global factor is one of the drivers of the fluctuating condition of financial markets in the world. Foreign investors are likely to reduce portfolio investment in emerging market due to global risks and uncertainty of monetary policy in developed countries (Adler G, Djigbenou, and Sosa, 2015).

Along with the liberalization of the financial system, there is an increasing trend of international capital flows to ASEAN especially Indonesia, Singapore, Malaysia, Philippines and Thailand. Figure 1 showed that capital inflows to ASEAN-5 sharply increased after global financial crisis. The greater capital inflows are triggered by lax global financial conditions (Bruno and Shin, 2015, Rey, 2015). In addition to the rapid growth of global liquidity, the global financial cycle also concerns of domestic regulator, particularly in emerging economies countries that periodically received International capital flows on a large scale.

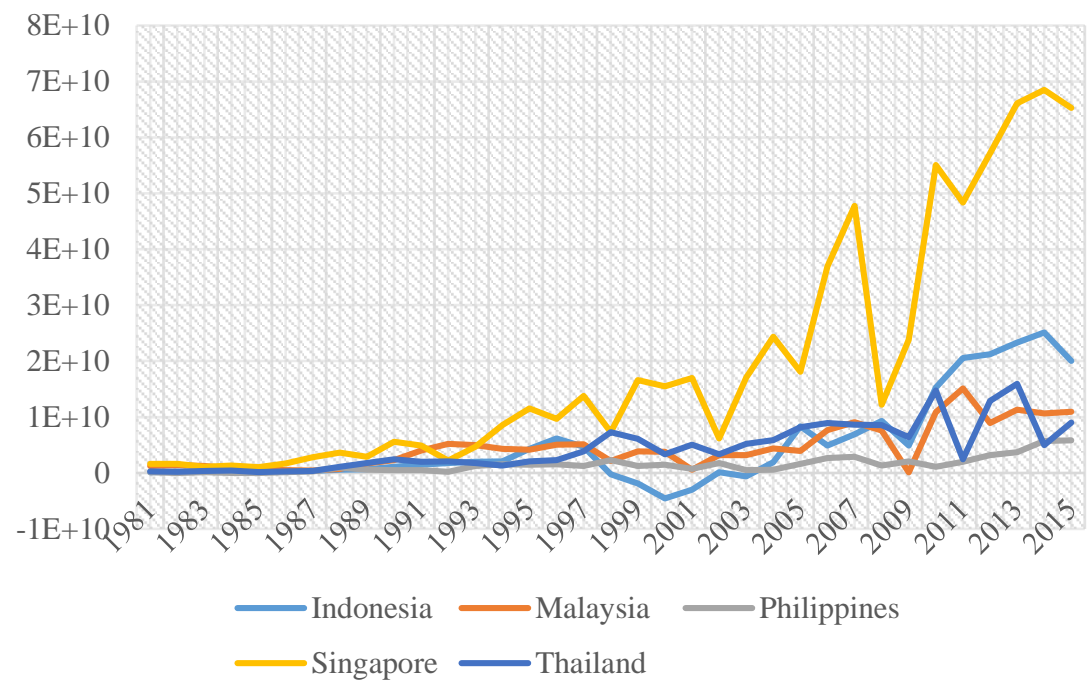

Figure 1 Capital inflows in ASEAN-5 (Million US\$)

Source: IMF

The movement of the global financial cycle is very volatile. It indicates how changes of sentiment in the markets affect EMEs financial conditions. Rey (2015) has triggered an interesting discussion about global financial cycle. She found that there was a global financial cycle in capital flows, asset prices and credit growth. This cycle was co-moves with the VIX, a measure of uncertainty and risk aversion of the markets. The sharp increase in global risks creates a fluctuation in the asset market so that it triggers portfolio outflows from EMEs (Mishra et al, 2014; Sahay et al, 2014). In tapering out period, equity and property prices decreased incisively. During this period of turmoil, Asian Emerging Market Economies was affected much more attention especially for ASEAN-5, namely Indonesia, Malaysia, Singapore, Thailand and Philippines.

In addition, the movement of Fed's policy as a driver of the global financial cycle have influenced international capital flows to ASEAN-5. The uncertainty of this implementation can stimulate uncertainty in financial market. asset prices are not spared from global conditions such as the global financial cycle and US 
monetary policy. They can disrupt domestic financial stability by increasing vulnerability to the global financial cycle. Nevertheless, empirical studies on the impact of the global financial cycle to EMEs financial markets are still rare. The research on the impact of the global financial cycle on the EMEs asset market did not give detail information in analyzing the implications for each country (Rey, 2015; Miranda-Agrippino and Rey, 2015; Ebeke and Kyobe, 2015; Banerjee et al., 2012). As Ebeke and Kyobe (2015) focus on the impact of global financial risk on the government bond markets of EMEs countries. In addition, Ciarlone et al (2009) focuses on the impact of global financial risk on the volatility of the EMEs exchange rate. Furthermore, Ananchotikul and Zhang (2014) also focus on the impact of global financial cycle on government bond markets in EME countries.

This study contributes to the literature in several ways. First, we examine the transmission of global financial cycle shocks to ASEAN-5 countries by using Structural Vector Autoregressive (SVAR) approach. We identify not only cyclical expansions or contraction in asset markets but also the impact of global financial cycle to asset markets in ASEAN-5 countries. Second, we investigate whether there are heterogeneous responses of ASEAN-5 countries to global financial cycle shocks. Third, we also identify the pattern of cycle in ASEAN-5 countries.

The rest of this study is organized as follows. Section 2 describes theoretical framework and literature review. Section 3 introduces the methodological framework and data. Section 4 discusses empirical results. Finally, section 5 presents the conclusions and recommendations.

\section{LITERATURE STUDY/HYPOTHESES DEVELOPMENT}

\subsection{Financial Cycle}

Recent studies that related to the financial cycle began to be a discussion among academicians and policy maker. The definition of financial cycle is still varied based on that focused research. Various studies that explain the definition of the financial cycle cannot be a commonly used reference. Generally, some studies refer to the definition and methodology of the business cycle from National Bureau of Economic Research (NBER). The definition proposed by Borio (2012) generally represents the definition of the financial cycle that the financial cycle is the interaction between the perceptions of value and risk, behavior on risk, and financial constraints, which are translated as booms Followed by bust. This definition is also in line with that of $\mathrm{Ng}$ (2011), which states that the financial cycle is a change in perceptions and attitudes toward financial risks over time. This definition is closely related to the recent procyclicality which is a popular issue in macroprudential policy.

\subsection{International Channel of Global Financial Cycle}

In a report released by the IMF (2016), components that close to VIX in the long run are bond yields, retail interest rates and bank loans, whereas stock market and exchange rate are closely related to VIX in short term. VIX represents the expectation of global financial market volatility which in the short run is expected to have a negative sign for this variable. An increase in the VIX index raises the expectation of global financial market volatility that could reduce bank lending, asset price, and credit growth. Higher international integration of financial markets also means that global financial factors have higher influenced for domestic financial markets in Emerging Market Economies. 
The global financial cycle gives an impact to financial conditions in EMEs through both quantity and price channels (Filardo et al, 2014). The most prominent quantity spillover channel operates through capital flows. Before and after the crisis, capital flow dynamics have been shaped in particular by portfolio flows. Cross-border financial flows, or concerns about them, also give rise to price spillover effects in particular through induced changes in interest rates, shaping financial conditions in the economy more broadly. Specifically, EM economy central banks may wish to avoid large and volatile interest rate differentials so that short-term rates become implicitly tied to those of advanced economies. At the same time, due to the greater integration into the global financial systems, longterm interest rates in EM economies have also become more closely tied to those in advanced economies (Turner, 2014). The literature has identified a number of channels through which monetary policy might have contributed to the build-up in financial imbalances. Most of these are thought to have worked through policy rates that were kept low for too long. Loose monetary policy (a low short-term rate) may have reduced the cost of wholesale funding for intermediaries, leading those intermediaries to build-up leverage (Adrian and Shin, 2008).

Domestic financial market conditions are influenced by perceptions of global investors, where investors will consider the perceptions of return on investment in the US relative to investment returns in developing countries. Thus, capital inflows are also influenced by the conditions of global financial cycle. If global risk aversion increases, it can lead to declining cross-border credit, declining asset prices, declining equity returns and weakening the exchange rate of a country. Some financial instruments such as stocks, bonds and loans have different responses to global financial risks. On the other hand, with the prospect of strong economic growth and higher interest rates can be an attraction for foreign investors to channel capital into the country (Kenç, Erdem, and Ünalmı, 2016).

\section{RESEARCH METHODOLOGY}

\subsection{Estimation Technique}

Previous studies have constructed the method to identify financial cycle using short-medium term cycle. The methodologies used are adapted from business cycle studies. Recent financial cycle studies portrays two analytical approaches (e.g. Aikman et al. (2010, 2013), Claessens et al.(2011), Drehmann et al. (2012)). The turning point analysis determines cyclical peaks and troughs within the time series using an algorithm, whereas the frequency based filter analysis is a statistical filter technique to isolate fluctuations with different frequencies. Our goal is to analyze the cyclical pattern of financial cycle series

The frequency based filter is a technique to study the behavior of cyclical movements by isolating the cyclical pattern of the underlying time series (Stremmel, 2015). In recent literature two common types of frequency based filters are used to visualize cyclical behaviours: the Hodrick Prescott (HP) filter and the band pass filter (BP). The HP filter, developed by Hodrick and Prescott (1981, 1997), basically splits the data series into trend and cycle components by applying a criterion function to penalize deviations from the trend by using prespecified weights (Comin and Gertler, 2006). The two-sided HP filter incorporates both historic and future information on the time series, whereas the one-sided HP filter only employs historical data. One sided HP filters are often used in the 
macroprudential literature due to using only past information (e.g. Dekten et al, 2014). The second frequency based filter technique is the BP filter developed by Christiano and Fitzgerald (2003). This is basically a two-sided moving average filter isolating certain frequencies in the time series.

In order to analyzes pattern of financial cycle in ASEAN-5 countries, this study employs frequency-based filter method, specifically Christiano and Fitzgerald band pass filter, which is used by Drehmann et al (2012) to identify financial cycle. This method allowed to capture duration and amplitude. The advantages of band pass filter could generate common cycle graph so that we can identify pattern of financial cycle. we observe ASEAN-5, namely Indonesia, Malaysia, Thailand, Singapore and Philippines. To analyze the response of asset markets to global financial cycle shocks, this study employs quarterly data from Q1 1990 to Q2 2016 except Philippines ${ }^{1}$. Residential property prices are from the data base of the Bank for International Settlements (BIS). For equity prices, the data was taken from Bloomberg ${ }^{2}$. All variables are measured in logarithms.

\subsection{Empirical Model}

In order to analyze the impact of global financial cycle on asset markets in ASEAN-5 Countries, we employ a structural VAR (SVAR) model with block exogeneity, which is first used by Cushman and Zha (1997) to identify monetary policy shocks and to examine the response of the Canadian economy to external shocks. Since this pioneering study, a growing number of studies (Gossé and Guillaumin, 2013; Mackowiak, 2007; Osborn and Vehbi, 2015; Sousa, 2014) have adopted a similar model. This estimation techniques preceded by several standard measures such as stationary test or stationary stochastic process (Ajija et.al, 2011) and determination of the optimal lag with lag order selection criteria. Sims (1980) states that if there is a simultaneous relationship between variables observed, the variables should be treated equally, no more endogenous and exogenous variables. The development in the SVAR model is done through the establishment of restrictions among variables in the system equation. The restriction or limitation is intended to separate the movement of the endogenous variables into several components based on the underlying shock.

Matsumoto (2011) used SVAR method that can capture heterogeneity of inter-state responses to global liquidity shocks, in contrast to panel methods commonly used in the study of global liquidity spillover effects on emerging countries (Psalida and Sun 2011; Brana, Djigbenou, and Prat 2012). This is important, given several other studies (Sousa and Zaghini 2007; Darius and Radde 2010; Chudik and Fratzscher 2011) found that the effects of global liquidity spillovers in various countries may vary, where these differences may be related to differences in economic structure or policy posture in the country -the state.

The SVAR model that used in this study consists of four variables with four equations. They are VIX index as a proxy of global financial cycle and the Fed Fund Rate as a proxy of the US monetary policy. For Asset markets, we employ residential property prices and equity prices. The specification of the VAR model in reduced form is,

\footnotetext{
${ }^{1}$ For Philippines, data on residential property price is available after Global Financial Crisis. Thus, we use residential property price index from 2008 to 2016.

${ }^{2}$ Average of asset prices as benchmark of asset markets each country.
} 


$$
A_{0} X_{t}=A(L) X_{t-1}+B \varepsilon_{t}
$$

Where $X_{t}$ is a vector with four variables used; $A_{0}$ is a contemporaneous relation among variables; $\mathrm{A}(\mathrm{L})$ is a finite-order matrix polynomial with the lag operator $\mathrm{L} ; \varepsilon_{t}$ is a vector of structural disturbance; and B is a non-zero diagonal matrix. Basically, there are several ways to place restrictions on the SVAR model, such as long run restriction, impact, and sign restriction. This restriction helps to identify the models and to insert the basic theory into the model.

The US monetary policy variable is regarded as independent variable, so that the variables that can influence FFR shock is a shock in the FFR itself. Hence, global financial cycle (VIX) is driven by US monetary policy. As small open economies, domestic asset markets are considered unable to influence the global conditions. Thus, the first equation in the VAR system is as follows:

$$
\begin{aligned}
& e_{F F R}=b_{11} \varepsilon_{F F R} \\
& e_{V I X}=b_{21} \varepsilon_{F F R}+\varepsilon_{V I X} \\
& e_{P S}=b_{31} \varepsilon_{F F R}+b_{32} \varepsilon_{V I X}+\varepsilon_{P S} \\
& e_{P P}=b_{41} \varepsilon_{F F R}+b_{42} \varepsilon_{V I X}+b_{43} \varepsilon_{P S}+\varepsilon_{P P}
\end{aligned}
$$

Thus, the VAR system specifications used are as follows with a total of 10 restrictions:

$$
\left[\begin{array}{c}
e_{F F R} \\
e_{V I X} \\
e_{P S} \\
e_{P P}
\end{array}\right]=\left[\begin{array}{c}
e_{F F R} \\
e_{V I X} \\
e_{P S} \\
e_{P P}
\end{array}\right]\left[\begin{array}{cccc}
1 & 0 & 0 & 0 \\
b_{21} & 1 & 0 & 0 \\
b_{31} & b_{32} & 1 & 0 \\
b_{41} & b_{42} & b_{43} & 1
\end{array}\right]
$$

To ensure the validity of the final model used, stability testing of model is needed with condition all the root lies inside the unit circle (absolute unit root less than one). If the condition is stable, it can be done with the next step which is Impulse Response Function (IRF).

\section{RESULT AND ANALYSIS}

\subsection{Cycle Analysis of Asset Markets}

Figure 2 shows the resulting equity price series. ASEAN-5 countries showed clearly episode of contraction in 2008/2009. It indicates the following of global financial crisis in US markets. Interestingly, Indonesian's equity markets appear different amplitude between before and after the global financial crisis. The amplitude of equity prices in episode of Asian economies crisis is lower than in episode of global financial crisis. It associated with foreign equities recorded in BEI which is still dominated by foreign investors. Therefore, the Indonesian stock market is more vulnerable to the negative sentiment in global markets considerably affects domestic Stock markets. Relatively, Malaysia and Singapore have similar equity market capitalization that foreign share ownership increased after Asian Financial crisis. 

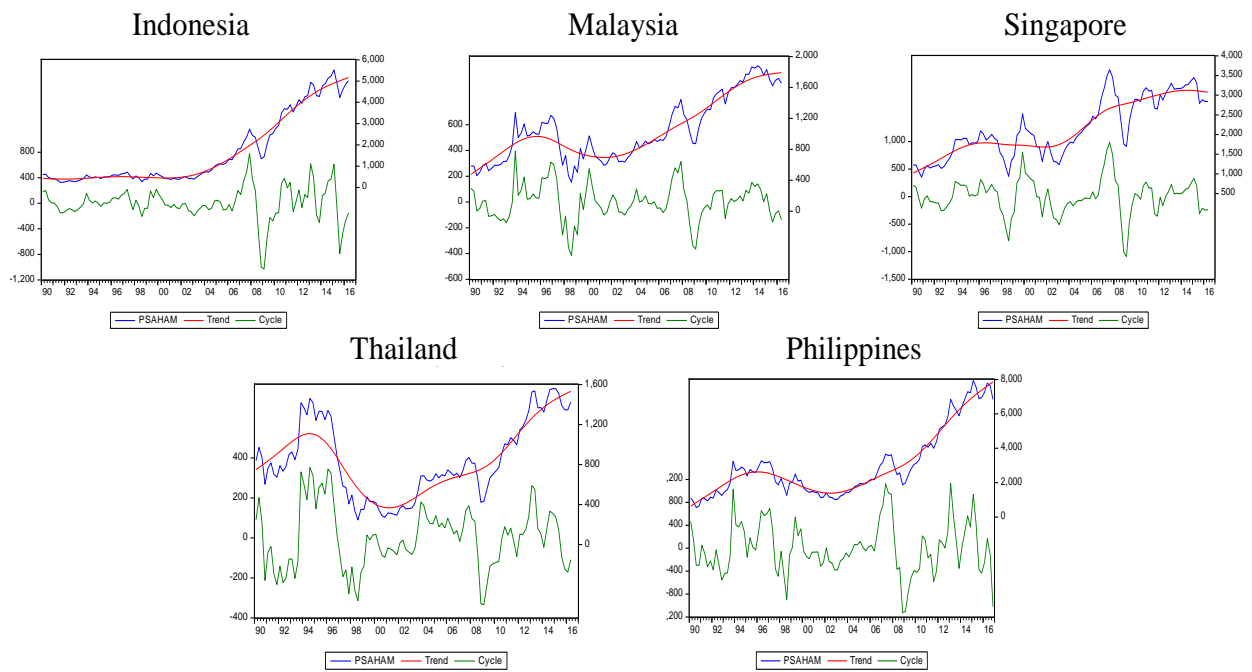

Figure 2 Trend and Cycle of Equity Prices; LHS: Trend and Cycle; RHS: Property Prices

The residential property price cycles in Indonesia, Malaysia and Thailand show different patterns and amplitudes over time. These countries did not show a clear and sharp pattern of repatriation like Singapore. During the observation period, Singapore had two throughs during the Asian economic crisis of 97/98 and the global financial crisis 07/08. Figure 3 shows that Singapore has a repetitious pattern such as deep amplitude occurred during the Asian economic crisis of 97/98 and the global financial crisis of 07/08. Singapore's residential property prices experienced peak phase in 2008 until then corrected in 2009. The low interest rates are the main drivers of property price boom (IMF, 2013). In addition, Singapore government give the permission of foreign investor to have an own property in Singapore. Although the regulation of foreign ownership in Singapore are very strict, capital inflow remains enormous because Singapore have excellent prospects. Based on research conducted by Savills Singapore, foreign property ownership is a $20 \%$ of total property transactions in 2009 . It indicates that foreign investors have a substantial contribution to property developments in Singapore. 

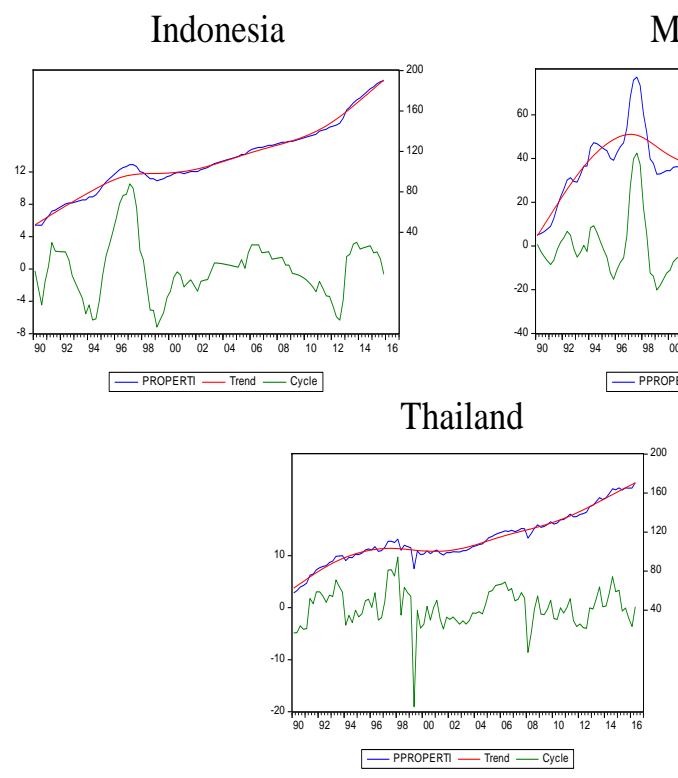

Malaysia

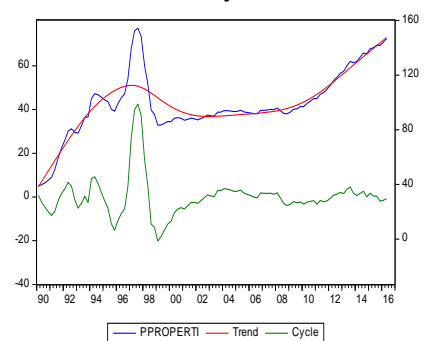

Singapore

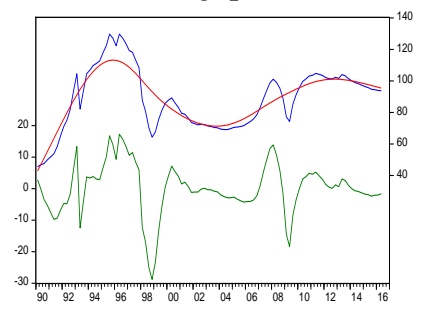

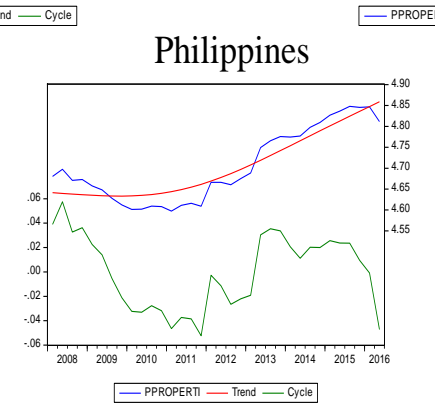

Figure 3 Residential Property Prices Cycle; LHS: Trend and Cycle; RHS: Property Prices

Interestingly, ASEAN-5 experienced a sharp rise in residential property prices in the second half of the 1999s, in many cases associated with liberalization and deregulation of the housing finance sector. Residential property prices were subsequently weak or fell in 1998, following the Asian crisis in 1997-1998. Indonesia and Singapore suggest higher amplitude in the 1990s that following the bubble property in Japan around 1990-1993, residential property prices in both countries fell In Thailand residential property prices started falling in 1997, vividly indicating the depth of the "Asian Financial Crisis."

The financial cycle in ASEAN-5 countries shows longer duration of expansion compared to the duration of contraction. The amplitude of residential property prices is greater in the Asian economic crisis than the global financial crisis. While the amplitude of equity cycles is deeper in global financial crisis than the Asian economic crisis. ASEAN-4 financial cycles represented by stock prices and property prices show longer duration of expansion compared to duration of contraction. The amplitude of the expansion phase is higher than the contraction phase amplitude. The deepest period of decline in ASEAN-4 during the Asian crisis of $97 / 98$ and the global financial crisis.

The sharp decreasing period in the Malaysian stock price cycle occurred during the Asian economic crisis, but in Indonesia it occurred during the global financial crisis. This can be seen from the composition of Indonesia's stock ownership which is still dominated by foreign investors so it is still very vulnerable to negative sentiment emerging from external. During the observation period in property prices, Singapore and Thailand had two through during the Asian economic crisis of 97/98 and the global financial crisis 07/08. The Indonesian and Malaysian property price cycles have the highest amplitude in Q2: 1994 - Q1: 1999. 
In contrast to Malaysia and Indonesia, Singapore and Thailand did not show a sharp and clear period of expansion in that period.

\section{Discussion}

In this section, we discuss the empirical results. We reveal the effect of global financial cycle shock on ASEAN-5 asset prices. Based on criteria of model selection by Andrews and Lu (2001) and the overall determination coefficient, lag criteria in this model is two. Fig. 4 presents the response of asset price variables to a 1-standard deviation increase in global financial cycle (i.e., a 1-standard deviation increase in the VIX). In short run, global financial cycle has a significant effect on equity price in ASEAN-5 countries. The shock of global financial cycle has an immediate and significant negative impact on equity prices. It indicates that global financial cycle shock reduces equity prices in ASEAN-5 countries. While global financial cycle is not significantly effect on residential property price in all ASEAN-5 countries. 

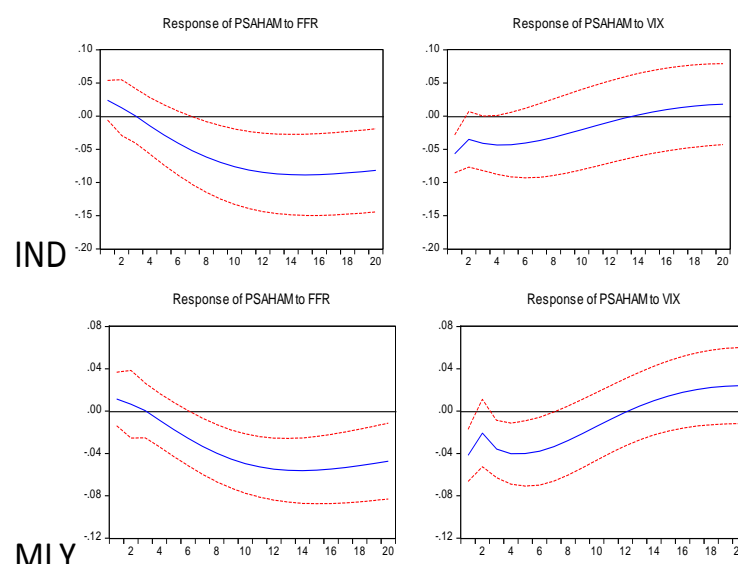

Response of PSAHAM to FFR

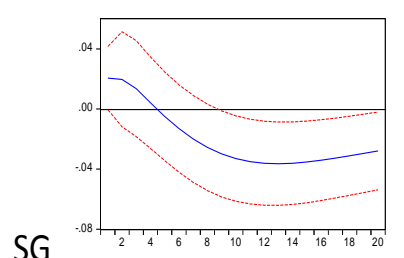

Response of PSAHAM to FFP
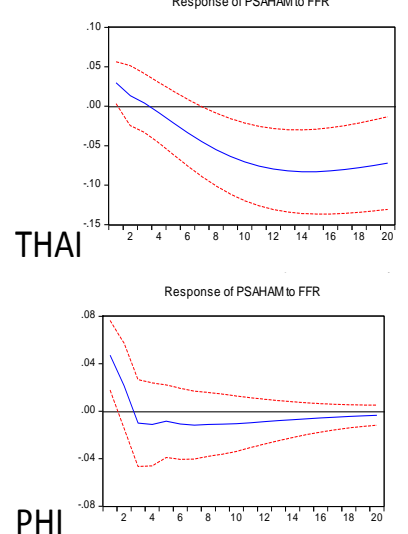

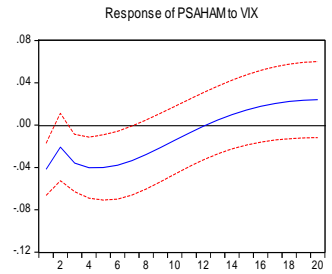

Response of PSAHAM to VIX

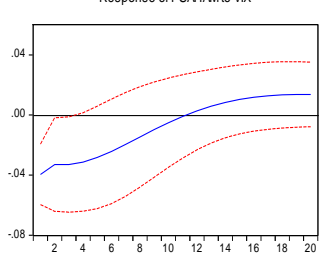

Response of PSAHAM to VIX

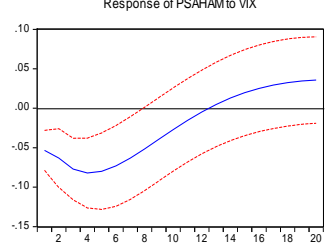

Response of PSAHAM to VIX

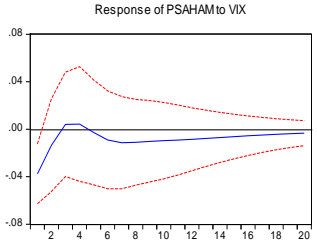

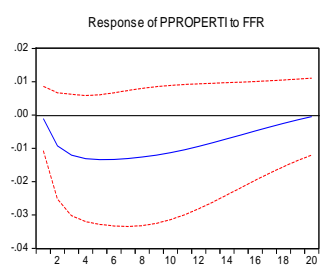
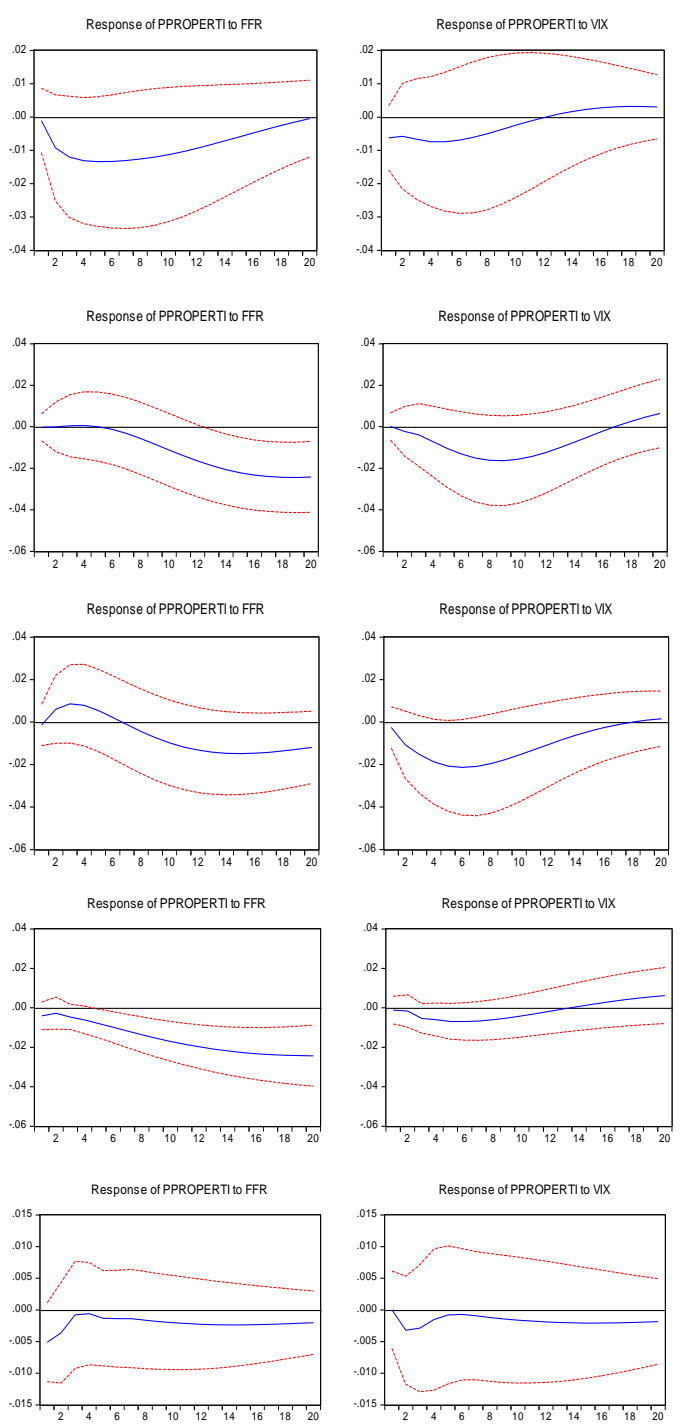

Fig 4 Response Asset Markets to Global Financial Cycle Shock in ASEAN-5 countries

The global financial cycle is closely related to US monetary policy. The US monetary policy can be a trigger for global financial cycle. Loose monetary policy lowers risk aversion and high VIX is followed by loose monetary policy. These results suggest that the increasing global financial cycle follows the tight US's monetary policy, while loose monetary policy occurs after VIX increases. Equity prices instantaneously give a negative response to the shock of global financial cycle. Equity price index is very sensitive to changes in the global financial cycle (See Fig. 4). Equity prices are more quickly respond to changes in the global 
financial cycle. It suggests that equity markets are an investment that considers forward looking measure. Thus, equity market movements are faster than residential property price. The size of the response of equity prices to global financial cycle shocks is relatively same within ASEAN-5 countries.

\section{Conclusion}

The impact of global financial cycle shocks on advanced financial conditions is well documented in the literature. However, there is little empirical evidence regarding the impact of global financial cycle on asset markets in Asian countries. This study aims to fill this gap in the literature by documenting evidence on the impact of global financial cycle shock on asset markets for ASEAN-5 countries. The financial cycle in ASEAN-5 countries shows longer duration of expansion compared to the duration of contraction. Our findings reveal strong evidence that global financial cycle shocks have significant effects on equity prices in ASEAN-5 countries which is consistent as forward-looking investment. Furthermore, our results show that the size of the response of equity prices to global financial cycle shocks is relatively same within ASEAN-5 countries. While global financial cycle gives different response on residential property price in ASEAN-5 countries. These differentiations are associated with the share of foreign holdings in property markets.

\section{References}

Abrigo, M. R. M., \& Love, I. (2015). Estimation of Panel Vector Autoregression in Stata: a Package of Programs. Working paper. University of Hawaii.

Adler, G., Djigbenou, M. S., \& Sosa, S. (2016). Global financial shocks and foreign asset repatriation: Do local investors play a stabilizing role? Journal of International Money and Finance, 60, 8-28.

Adrian, T., \& Shin, H. S. (2012) "Procyclical Leverage and Value-at-Risk" Federal Reserve Bank of New York Staff Report 338, http://www.newyorkfed.org/research/staff reports/sr338.html.

Akinci, Ö. (2013). Global financial conditions, country spreads, and macroeconomic fluctuations in emerging countries. J. Int. Econ. 91 (2), 358371.

Alamsyah, H., Adamanti, J., Yumanita, D., \& Astuti, R. I. (2014). Siklus Keuangan Global. Bank Indonesia Working Paper, WP/ 8 /2014.

Anas, J., \& Ferrara, L. (2002), Detecting Cyclical Turning Point: The ABCD Approach and Two Probabilistic Indicators. Quarterl Journal of Economic Research.

Ananchotikul, N., \& Zhang, L., (2014). Portfolio flows, global risk aversion, and asset prices in emerging markets. IMF Working Paper WP/14/156 (August). 
Assenmacher-Wesche, K., \& Gerlach, S. (2008). Financial Structure and the Impact of Monetary Policy on Asset Prices. Swiss National Bank Working Paper.

Banerjee, R., Devereux, M. B., \& Lombardo, G. (2016). Self-oriented monetary policy, global financial markets and excess volatility of international capital flows. Journal of International Money and Finance, 68, 275-297

Belke, A., Bordon, I. G., \& Hendricks, T. W. (2010). Global liquidity and commodity prices-a cointegrated VAR approach for OECD countries. Applied Financial Economics, 20(3), 227-242.

Brana., \& Prat. (2016). The effects of global excess liquidity on emerging stock market returns: Evidence from a panel threshold model. Economic Modelling 52 (2016) 26-34

Bruno., \& Shin. (2015). Capital flows and the risk-taking channel of monetary policy. Journal of Monetary Economics, 71, 119-132.

Canova, F., \& Ciccarelli, M. (2013). Panel Vector Autoregressive Models -A Survey. ECB Working Papers Series, No. 1507 / January 2013

Christiano, L. J., Fitzgerald, T. J. (2003). The Band Pass Filter. International Economic Review, 44(2), 435 - 465.

Chudik, A., \& Fratszcher, M. (2011). Identifying the global transmission of the 2007-09 financial crisis in a GVAR model. Eur. Econ. Rev. 55, 325-339.

Claessens, S., Kose, M. A., \& Terrones, M. (2011). How Do Business and Financial Cycles Interact?. IMF Working Paper, WP/11/88.

Cushman, D. O., \& Zha, T., (1997). Identifying monetary policy in a small open economy under flexible exchange rates. J. Monet. Econ, 39, 433-448.

Drehmann, M., Borio, C., \& Tsatsaronis, K. (2012). Characterizing the financial cycle: don't lose sight of the medium term. BIS Working Papers No 380.

Ebeke, C., \& Kyobe, A. (2015). Global financial spillovers to emerging market sovereign bond markets. IMF Working Paper WP/15/141.

Ekananda, M. (2016). Analisis Ekonometrika Time Series Edisi 2. Mitra Wacana Media.

Falianty, T. (2016). Capital Flows, Macro Prudential Policy, and Property Sector. IJABER, 14(10), 6935-6958.

Filardo, A., Genberg, H., \& Hofmann, B. (2014). Monetary Analysis and The Global Financial Cycle: An Asian Central Bank Perspective. BIS Working Papers No 463.

Fratzscher, M., Lo Duca, M., \& Straub, R. (2013). On the international spillovers of US quantitative easing. ECB Working Paper No. 1557. 
Hastuti, F. (2016). Analisa Dampak Perubahan Siklus Keauangan Global Pada Kredit dan Harga Aset Studi Kasus Indonesia. LHP No. 18/DRK/ 2016 Bank Indonesia.

IMF. (2016). Global financial stability report. International Monetary Fund, Washington DC (October).

Kenç., Erdem., \& Ünalmı. (2016). Resilience of emerging market economies to global financial Conditions. Central Bank Review.

Mishra, P., Moriyama, K., N'Diaye, P., N\& guyen, L. (2014). Impact of Fed tapering announcements on emerging markets. IMF Working Paper No. $14 / 109$.

Miranda-Agrippino, S., \& H, Rey. (2015). World Asset Markets and The Global Financial Cycle. NBER working paper series.

Ng, T. (2011). The Predictive Content of Financial Cycle Measures for Output Fluctuations. BIS Quarterly Review.

Rey, H. (2015). Dilemma not Trilemma: The global Financial Cycle and Monetary Policy Independence. NBER Working Paper No. 21162.

Sahay, R., et al. (2014). Emerging market volatility: lessons from the Taper Tantrum. IMF Staff Discussion Notes No. 14/9, Washington DC.

Yildirim, Z. (2016). Global financial conditions and asset markets: Evidence from fragile emerging economies. Economic Modelling, 57, 208-220. 